\title{
Evaluation of physicochemical, bioactive composition and profile of fatty acids in leaves of different olive cultivars
}

\author{
Bruna da Fonseca Antunes ${ }^{1}$, Deborah Murowaniecki Otero ${ }^{2 *}$ (D), Daisa Hakbart Bonemann ${ }^{3}$, \\ Anderson Schwingel Ribeiro ${ }^{3}$, Andressa Carolina Jacques ${ }^{4}$, Rui Carlos Zambiazi ${ }^{1}$
}

$10.1590 / 0034-737 X 202168060002$

\begin{abstract}
Olive leaves are agro-industrial residues resulting from pruning and / or olive harvesting, and are used in animal feed, as an organic fertilizer and as a source of compound extraction for various applications. This study aimed to carry out the physicochemical characterization, main bioactive compounds and the fatty acid profile of olive leaves from the cultivars Frantoio, Koroneike, Manzanilha, Arbosana and Arbequina. Proximal composition, pH, titratable acidity, minerals by MIP OES, bioactive compounds were determined by spectrophotometry, oleuropein and tocopherols by high performance liquid chromatography and the fatty acid profile by gas chromatography. The olive leaves had a high content of fibers and proteins, the predominant minerals were potassium and calcium, in addition the olive leaves had a high content of bioactive compounds, mainly flavonoids and carotenoids and the cultivar Koroneike had a higher content of oleuropein compared to the others. In relation to tocopherols, á-tocopherol stood out from the other tocopherols with the maximum concentration $\left(63436.79 \mathrm{mg}_{100 \mathrm{~g}^{-1}}\right)$ measured in the cultivar Arbequina. In view of the results found, it is concluded that olive leaves are sources of macromolecules, bioactive compounds and fatty acids, which can be extracted and applied in the most diverse areas.
\end{abstract}

Keywords: nutraceutical; Olea europaea L.; by products

\section{INTRODUCTION}

Oliveira (Olea europaea L.), is reported as one of the fruits cultivated for the longest time, being a rounded and medium sized tree, the color of the trunk and the density of the crown are differentiated according to the cultivation and cultivar conditions, and its fruits, the olives, serve as raw material for the extraction of olive oil and for the production of preserved olives (Coutinho, 2007; Guo et al., 2018).

The olive tree produces a large amount of leaves, which in the juvenile period are shorter and thicker, and in the adult period, the leaves are longer and thinner. Olive leaves are considered as agro-industrial residues, as they are obtained after pruning and / or harvesting the olives, and are normally used in animal feed or as organic fertilizer. Thus, the leaves, together with the oil post-extraction bagasse, are considered co-products of the olive industry (Fernández-Bolaños et al., 2006; Tarchoune et al., 2019; Lama-Muñoz et al., 2020).

The high consumption of olive-based products in the Mediterranean diet, for example, is related to a lower incidence of chronic diseases associated with oxidative damage, such as diabetes, some types of cancer and cardiovascular and neurodegenerative diseases, which is mainly related to the high content of phenolic compounds. Among the phenolic compounds present in the fruit and in the olive leaves, oleuropein and hydroxytyrosol stand out (Visioli \& Galli, 2002; Gorzynik-Debicka et al., 2018).

The industrial exploitation of leaves may represent an option for valuing the planting of olive trees, due to the increased demand for natural products by various industrial segments, such as food and pharmaceuticals, in addition

Submitted on August 18 $8^{\text {th }}, 2020$ and accepted on February 14th 2021.

${ }^{1}$ Universidade Federal de Pelotas, Faculdade de Agronomia Eliseu Maciel, Departamento de Ciência e Tecnologia Agroindustrial, Pelotas, Rio Grande do Sul, Brazil. brunafonsecaantunes@gmail.com; zambiazi@gmail.com

${ }^{2}$ Universidade Federal da Bahia, Escola de Nutrição, Departamento de Ciência dos Alimentos, Salvador, Bahia, Brazil. deborah.m.otero@gmail.com

${ }^{3}$ Universidade Federal de Pelotas, Laboratório de Metrologia Química, Centro de Ciências Químicas, Farmacêuticas e de Alimentos, Pelotas, Rio Grande do Sul, Brazil. daisa_bonemann@yahoo.com.br; andersonsch@hotmail.com

${ }^{4}$ Universidade Federal do Pampa, Engenharia de Alimentos, Bagé, Rio Grande do Sul, Brazil. andressajacques@hotmail.com

*Corresponding author: deborah.m.otero@gmail.com 
to indicating an alternative to minimize waste disposal and environmental impact (Fernández-Bolaños et al., 2006; Galanakis et al., 2018; Jabalbarezi-Hukerdi et al., 2018).

Olive leaves are considered a material rich in micro and macro nutrients, as well as in bioactive compounds and for this reason they become an alternative source with outstanding nutritional and biological potential. The leaves have proven nutraceutical potential, being mainly used by the pharmaceutical industry, however the leaves or their extracts can also be incorporated into food products due to their characteristics. Among the bioactive compounds, simple phenolics, flavonoids and secairidoides stand out (Rosa et al., 2019; Talhaoui et al., 2015; Rahmanian et al., 2015).

Leaf characterization studies allow adding value to the raw material, reusing raw material and, consequently, adding value, generating jobs along the chain, and being used in several promising areas (Lorini et al., 2020). In view of the cultivation of the olive tree in the southern region of Brazil, the scarcity of studies on the chemical and bioactive potential of the leaves grown in that region, and due to the fact that the composition of the vegetables is influenced by many factors, this study aimed to objective to characterize the olive leaves of different cultivars, in terms of the physical aspect, chemical composition, bioactive and fatty acids aiming to obtain results that can add value to this co-product, arousing the interest of its use in several areas.

\section{MATERIAL AND METHODS}

\section{Samples}

Olive leaves from five cultivars (Arbequina, Koroneiki, Arbosana, Frontoio and Manzanilha) were acquired in an olive grove located in the city of Pinheiro Machado / RS (31 ${ }^{\circ} 29^{\prime} 59.4^{\prime \prime} \mathrm{S}$ and 53³0’32.7" W) in December 2019 (springer). Leaf samples were collected from the outermost part of 50 trees older than 5 years and planted at a distance (7 x $5 \mathrm{~m}$ ). In total, about $2 \mathrm{~kg}$ of leaves of each cultivar were obtained, at different times, which were homogenized, packaged and transported to the Chromatography Laboratory of the Federal University of Pelotas (UFPel / Pelotas / RS). Then, the leaves were frozen in liquid nitrogen, crushed, ground and placed in polyethylene containers and subjected to $-80^{\circ} \mathrm{C}$ and aliquots removed for analysis, which were carried out in triplicate experiments.

\section{Physicochemical determinations}

The analyzes were performed according to the procedures described by the Association of Official Analytical Chemists (1995). The moisture content was determined by weight loss by drying in an oven with air circulation (Ethik Technology, EST. 402, Brazil) at $105^{\circ} \mathrm{C}$ until constant weight. The ash content was determined by muffle incineration (Quimis ${ }^{\circ} 0318 \mathrm{M} 24$ ) at $550{ }^{\circ} \mathrm{C}$ until constant weight. Protein content was determined using the Micro Kjeldahl method. The carbohydrate content was determined by difference (Equation 1). The determination of the lipid content was carried out in a Soxhlet extractor, using hexane as a solvent.

$\% \mathrm{C}=100-(\%$ Umidade $+\%$ Lipídios $+\%$ Proteínas +
+ Cinzas $)$

The fiber content was determined by extraction in an acid solution, using about $2 \mathrm{~g}$ of sample, and then incinerated in a muffle at $550^{\circ} \mathrm{C}$ (Quimis $\left.{ }^{\circledR} 0318 \mathrm{M} 24\right)$. The titratable acidity was determined by potentiometry, and the $\mathrm{pH}$ was determined using a bench measurer (MS TECNOPON mPA - 210) calibrated with buffer solutions pH 4.0 and 7.0. For reading, the leaves were diluted in water and subjected to homogenization. Titration was done with 0.1 M sodium hydroxide to $\mathrm{pH}$ between 8.2-8.4.

For the determination of minerals, approximately 250 mg of sample was used, which was decomposed with $\mathrm{HNO}_{3} 65 \% \mathrm{v} / \mathrm{v}$ distilled in a digestion block with reflux system coupled to the digestion tubes, according to the methodology used by Oreste et al. (2013), for further quantification of minerals (Table 1) in an microwaveinduced plasma optical emission spectrometer from Agilent Technologies, model 4200 (Melbourne, Australia). The results were expressed in micrograms per gram of sample $\left(\mathrm{mg} \mathrm{g}^{-1}\right)$.

\section{Determination of compounds present in leaves}

The following compounds were determined on olive leaves: flavonoids, phenolic compounds, condensed and hydrolyzable tannins, carotenoids, chlorophylls, tocopherols and oleuropein.

\section{Phenolic compounds content}

The The sheets were analyzed for the content of phenolic compounds present using the method described

Table 1: Minerals analyzed and their respective wavelengths for detection

\begin{tabular}{lc}
\hline Analyte & Wavelength $(\mathbf{n m})$ \\
\hline $\mathrm{Al}$ & 396.1 \\
$\mathrm{~B}$ & 249.7 \\
$\mathrm{Ca}$ & 393.3 \\
$\mathrm{Cu}$ & 324.7 \\
$\mathrm{Fe}$ & 371.9 \\
$\mathrm{~K}$ & 766.4 \\
$\mathrm{Mg}$ & 285.2 \\
$\mathrm{Mn}$ & 403.0 \\
$\mathrm{Na}$ & 588.9 \\
$\mathrm{P}$ & 213.6 \\
$\mathrm{Zn}$ & 213.8 \\
\hline
\end{tabular}


by Kubola \& Siriamornpun (2008), which consists of adding $0.5 \mathrm{~mL}$ of the sample, $2.5 \mathrm{~mL}$ of the $0.2 \mathrm{~N}$ reagent and after 5 minutes add $2 \mathrm{ml}$ of sodium carbonate solution (7.5\%). The mixture was kept at room temperature for $2 \mathrm{~h}$, in the absence of light, and the absorbance was determined at $725 \mathrm{~nm}$ in a spectrophotometer (JENWAY, $6705 \mathrm{UV} /$ Vis, Spain). For calibration, a standard curve of gallic acid (30 to $500 \mu \mathrm{g} . \mathrm{mL}^{-1}$ ) was constructed. were analyzed for the content of phenolic compounds present using the method described by Kubola \& Siriamornpun (2008), which consists of adding $0.5 \mathrm{~mL}$ of the sample, $2.5 \mathrm{~mL}$ of the $0.2 \mathrm{~N}$ reagent and after 5 minutes add $2 \mathrm{ml}$ of sodium carbonate solution $(7.5 \%)$. The mixture was kept at room temperature for $2 \mathrm{~h}$, in the absence of light, and the absorbance was determined at $725 \mathrm{~nm}$ in a spectrophotometer (JENWAY, 6705 UV / Vis, Spain). For calibration, a standard curve of gallic acid (30 to $500 \mu \mathrm{g} \cdot \mathrm{mL}^{-1}$ ) was constructed. The results were expressed in $\mathrm{mg}$ equivalent of gallic acid per $100 \mathrm{~g}$ of dry matter (mg EAG. $\left.100 \mathrm{~g}^{-1}\right)$.

\section{Flavonoids content}

For quantification of total flavonoids, $500 \mu \mathrm{l}$ of $2 \%$ aluminum chloride in methanol were added to $100 \mu \mathrm{L}$ of extract and $50 \mathrm{~mL}$ of distilled water (Funari \& Ferro, 2006). The reading of the total flavonoid content was made in a spectrophotometer $(425 \mathrm{~nm})$, using a standard curve of quercetin for quantification purposes. The results were expressed as milligram equivalents of quercetin per 100 grams of dry matter (mg EQ $\left.100 \mathrm{~g}^{-1}\right)$.

\section{Assay of tannins}

The total content of condensed tannins was estimated colorimetrically according to the method of Price et al. (1978), with adaptations, reading on an (JENWAY, 6705 UV/Vis, Spain), at a wavelength of 500 $\mathrm{nm}$. Quantification was based on the establishment of a standard curve and the results were expressed in milligrams of catechin equivalent per gram of leaf weight

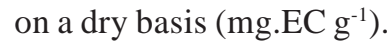

The total content of hydrolyzed tannins was estimated colorimetrically according to the method of Brune et al. (1991). The reading was performed on an (JENWAY, 6705 UV/Vis, Spain), at a wavelength of $680 \mathrm{~nm}$, using methanol to reset the equipment. Quantification was based on the establishment of a standard curve and the results expressed in milligrams of gallic acid equivalent per gram of leaf weight on a dry basis ( $\mathrm{mg} \mathrm{EAG} \mathrm{g}^{-1}$ ).

\section{Carotenoids content}

To evaluate the concentration of total carotenoids in leaves, the Rodriguez-Amaya (2001) methodology was used. Different absorbances were used to perform the readings: for â-carotene the wavelength used was 450 $\mathrm{nm}, 445 \mathrm{~nm}$ for á-carotene, zeaxanthin was read at $449 \mathrm{~nm}$ and $470 \mathrm{~nm}$ for lycopene. To quantify the carotenol contents, Equation 2 was used and the results expressed in milligrams per $1 \mathrm{~g}$ of dry matter $\left(\mu \mathrm{g} \cdot \mathrm{g}^{-1}\right)$.

Carotenoids $\left(\mu \mathrm{g} \cdot g^{-1}\right)=\underline{\text { Absorvance } x \text { extract volume }\left(m L \times 10^{\underline{6}}\right.}$ sorption coefficient $x 100 x$ sample weight $(g)$

(Equation 2)

\section{Assay of chlorophylls}

To assess the concentration of chlorophylls in the leaves, $1 \mathrm{~g}$ of leaves was weighed, added to $5 \mathrm{~mL}$ of $80 \%$ acetone (v/v) and centrifuged (Eppendorf $5430 \mathrm{R}$, Germany) for 15 minutes at 3,000 and then the supernatant transferred to $25 \mathrm{ml}$ flask and the volume was adjusted with $80 \%$ acetone. The extract was submitted to absorbance reading (647 and $663 \mathrm{~nm}$ ) in a spectrophotometer (JENWAY, 6705 UV / Vis, Spain), using $80 \%$ acetone as the equipment blank. For the determination of total chlorophylls, 'a' and 'b', Equations 3, 4 and 5, established by Lichtenthaler (1987) were used. The results were expressed in milligrams per $\mathrm{g}$ of leaf on a dry basis $\left(\mathrm{mg} \mathrm{g}^{-1}\right)$.

Total $\mathrm{Chl}=7,15\left(\mathrm{~A}_{663}\right)+18,71\left(\mathrm{~A}_{647}\right) \quad$ (Equation 3)

$\mathrm{Chl}^{\prime} \mathrm{a}^{\prime}=12,25\left(\mathrm{~A}_{663}\right)-2,79\left(\mathrm{~A}_{647}\right) \quad$ (Equation 4)

Chl ${ }^{\prime} b^{\prime}=21,50\left(\mathrm{~A}_{663}\right)-5,10\left(\mathrm{~A}_{647}\right) \quad$ (Equation 5)

\section{Assay of oleuropein}

Mass spectrometry-coupled liquid chromatography (LC-MS) was used to assess the content of Oleuropein in olive leaves. Extracts were produced by weighing $100 \mathrm{mg}$ of olive leaves added to $990 \mu \mathrm{L}$ of methanol (90\%) HPLC grade acidified with formic acid $(0.1 \%)$. As an internal standard, $10 \mu \mathrm{L}$ of reserpine $\left(1 \mathrm{mg} \cdot \mathrm{mL}^{-1}\right)$ was used as described by De Vos et al. (2007). The extract was submitted for 15 minutes in an ultrasonic bath (Unique, 1400A, Brazil) at a temperature of $25^{\circ} \mathrm{C}$ and subsequently centrifuged (Eppendorf $5430 \mathrm{R}$, Germany) at $12000 \mathrm{rpm}$ for 10 minutes at $4{ }^{\circ} \mathrm{C}$. For oleuropein extraction, the supernatant was added with $1 \mathrm{~mL}$ of methanol (already described), filtered on nylon filters with a pore of $0.45 \mu \mathrm{m}$ and then injected in UFLC (UFLC LC-20, Shimadzu, Japan) coupled to a high resolution quadrupole-time-of-flight mass spectrometer (Maxis Impact, Bruker Daltonics, Bremen, Germany). For chromatographic separation, a Luna C18 column (75x2 mm) (MicroSolv Technology Corporation, Leland, NC, USA) was used. The mobile phases were: water acidified with $0.1 \%$ formic acid (eluent A) and acetonitrile (eluent B). The gradient used was (min: \%B): (0:10); (2:10); (10:75); $(3: 75) ;(18: 90) ;(21: 90) ;(23: 10)$ and (30:10). The flow was constant $\left(0.2 \mathrm{ml} \mathrm{min}^{-1}\right)$ and the column temperature at $40^{\circ} \mathrm{C}$.

The mass spectrometer was operated in negative ESI mode, with spectra acquired over a mass range of 50 to 
$1200 \mathrm{~m} / \mathrm{z}$. The acquisition parameters were: drying gas at 8 L.min ${ }^{-1}$, nebulization gas pressure $\left(\mathrm{N}_{2}\right) 2$ bar, capillary voltage at $4 \mathrm{kV}$, drying gas at $8 \mathrm{~L} \cdot \mathrm{min}^{-1}$, source temperature $180^{\circ} \mathrm{C}, 150 \mathrm{Vpp}$ RF collision; $70 \mathrm{~ms}$ transfer and $5 \mathrm{~ms}$ prepulse storage. For calibration of the equipment, $10 \mathrm{mM}$ sodium formate (from 50 to $1200 \mathrm{~m} / \mathrm{z}$ ) was used. In addition, the collision energy values were adjusted: $\mathrm{m} / \mathrm{z}$ 100, $15 \mathrm{eV}$; m/z 500, $35 \mathrm{eV} ; \mathrm{m} / \mathrm{z}$ 1000, $50 \mathrm{e} \mathrm{V}$ and using nitrogen as collision gas. For identification of oleuropein, a standard curve was used. And the results expressed in micrograms equivalent to the standards per gram of dry sample $\left(\mu g^{-1}\right)$.

\section{Assay of tocopherols contents}

For the determination of tocopherols, an extract was performed according to Rodriguez-Amaya (2001), which was centrifuged (Eppendorf $5430 \mathrm{R}$, Germany) for $6 \mathrm{~min}$ at $9.000 \mathrm{rpm}$. The supernatant was collected and $20 \mu \mathrm{L}$ were injected into the liquid chromatograph of the HPLCShimadzu system (UFLC LC-20, Shimadzu, Japan), with automatic injection and fluorescence detector, with excitation and emission wavelengths of 290 and $330 \mathrm{~nm}$, respectively. For chromatographic separation, a RP-18 column $(5 \mu \mathrm{m}$ x $4.6 \mathrm{~mm}$ x $150 \mathrm{~mm}$ ) with an octadecyl stationary phase was used, being operated at $25^{\circ} \mathrm{C}$ with a flow of $1.0 \mathrm{~mL}$.min-1. The separation took place by gradient elution, being used as mobile phase: methanol, acetonitrile and methanol (Zambiazi, 1997). To quantify the tocopherols, the peak area was calculated and compared with the retention times (TR) of each standard, as follows: delta (6.5 min), gamma (7.4 $\mathrm{min})$ and alpha ( $8.3 \mathrm{~min})$. The results were expressed in micrograms equivalent to the standards per 100 grams of dry sample $\left(\mu \mathrm{g} .100 \mathrm{~g}^{-1}\right)$.

\section{Fatty acid profile}

For the fatty acid profile in the leaves, $20 \mathrm{~g}$ of sample were dried $\left(60^{\circ} \mathrm{C}\right)$ in an oven for about two hours. After removing the excess moisture (once the samples were frozen), the lipids were extracted (Bligh-Dyer, 1959) with subsequent evaporation (in a water bath) of the solvent. For the derivatization of fatty acids, $45 \mathrm{mg}$ of oil were dissolved in petroleum ether and $0.5 \mathrm{~N} \mathrm{HCl}$ in methanol (1 $\mathrm{ml}$ and $12 \mathrm{~mL}$ respectively), stirred and subjected to $65^{\circ} \mathrm{C}$ for one hour. Afterwards, it was cooled to room temperature, and $5 \mathrm{~mL}$ of isooctane and $6 \mathrm{~mL}$ of distilled water were added, under agitation (Zambiazi, 1997). An aliquot of the phase rich in fatty acid methyl esters (n-hexane) was injected into a Perkin Elmer Clarus 500 gas chromatograph equipped with an FID detector and a Carbowax20 M ID $0.25 \mu \mathrm{m}$ column with dimensions $30 \mathrm{mx}$

$0.25 \mathrm{~mm}$, coated with polyethylene glycol. The column temperature was started at $90{ }^{\circ} \mathrm{C}$, and maintained for 1.0 minute, gradually increasing by $12{ }^{\circ} \mathrm{C}$ per minute until reaching $160{ }^{\circ} \mathrm{C}$, maintained for 3.5 minutes, after a new linear increase of $1,2{ }^{\circ} \mathrm{C}$ per minute to $190{ }^{\circ} \mathrm{C}$, with a linear increase of $15^{\circ} \mathrm{C}$ per minute to $230^{\circ} \mathrm{C}$, which remained for

15 minutes. The injector had a temperature of $230{ }^{\circ} \mathrm{C}$ and the detector at $250^{\circ} \mathrm{C}$. The carrier gas was nitrogen at $1.5 \mathrm{~mL} \cdot \mathrm{min}^{-1}$ (Zambiazi, 1997). For identification of fatty acids, comparisons were made with comparison of retention times of the mixture of methyl ester standards (Sigma Chemicals Co., St. Louis, USA). Results were expressed as relative percentage of fatty acids.

\section{Statistical analysis}

The results obtained were expressed as means with standard deviation, referring to determinations carried out in triplicate. Using the SAS statistical program, analysis of variance (ANOVA) and the means comparison test (Tukey) were performed at a significance level of $5 \%$.

\section{RESULTS AND DISCUSSION}

\section{Physicochemical determinations}

From the results obtained in the physicochemical analyzes, it is observed that the olive leaves are constituted in greater quantity by water, followed by the fraction of carbohydrates and the protein content, also emphasizing a high fiber content (Table 2).

The moisture content of the olive leaves varied from 48.48 to $55.79 \%$, with the leaves of the cultivars Manzanilha and Arbosana showing the highest levels. Cavalheiro et al. (2015) describe moisture values that varied between the cultivars analyzed, from 39.30 to $64.80 \%$, with the cultivar Arbosana having a content of $59.33 \%$ and Koroneike of $61.91 \%$.

In the olive leaves it was found an ash content that varied from 3.00 to $4.38 \%$ with the highest concentration attributed to the leaves of the cultivar Koroneike. Similar levels were found by Cavalheiro et al. (2014) when evaluating the Arbequina cultivar from the city of Caçapava do Sul.

The fiber content of olive leaves varied from 9.32 to $11.02 \%$. Coppa et al. (2017), who evaluated commercial olive leaves, found a fiber content of $14.55 \%$, a result similar to that found in this work, as well as Erbay \& Icier (2009) when evaluating olive leaves grown in Turkey, which found a value of $13.95 \%$. It is evident that the olive leaf is a rich source of fiber, and the intake of foods enriched or fortified with fibers can provide a relevant alternative to increase the content of this nutrient (Jane et al., 2019).

The lipid content of the leaves varied from 3.77 to $7.85 \%$, with the cultivar Arbosana presenting the highest percentage. Cavalheiro et al. (2015) report an average lipid content in olive leaves of $9.50 \%$, with the leaves of the cultivar Arbosana having a content of $9.80 \%$ and Koroneike of $9.19 \%$. However, Boudhrioua et al. (2009) 
report lipid contents from 1.05 to $1.30 \%$ in olive leaves of the cultivars Chemlali, Chemchali, Zarrazi and Chetoui, all cultivated in Tunisia. Martín-García et al. (2003) evaluated olive leaves grown in Spain, and found a lipid content of $3.21 \%$. This information is important, especially if the fatty acids found in the lipid fraction of olive leaves are essential.

A protein content was found in the olive leaves that varied from 12.69 to $17.07 \%$, and the leaves of the cultivar Manzanilha presented the highest percentage. These values are higher than those found by several studies, in which it averaged 7\% (Martín-García et al., 2003; Boudhrioua et al., 2009). Cavalheiro et al. (2015) report levels of 10 and $50 \%$ of protein in leaves of cultivars Arbosana and Koroneike, respectively, and of $12.24 \%$ in leaves of cultivar Arbequina (Cavalheiro et al., 2014).

The olive leaves had a carbohydrate content that varied from 8.63 to $17.55 \%$, and the leaves of the cultivar Frantoio had the highest content. Boudhrioua et al. (2009) found an average carbohydrate content of $40 \%$ for the leaves of the cultivars Chemlali, Chemchali, Zarrazi and Chetoui. However, studies report that the carbohydrate content varied from 8.74 to $32.63 \%$ among cultivars Arbequina, Ascolano, Arbosana, Negrinha do Freixó, Koroneiki and Grappolo (Cavalheiro et al., 2014; Cavalheiro et al., 2015).

It was found a variation of acidity for olive leaves from 17.96 to $19.26 \%$, and a $\mathrm{pH}$ that varied from 5.25 to 5.89. In a study by Lunkes \& Hashizume (2014), when evaluating the titratable acidity and the $\mathrm{pH}$ of commercial olive leaf teas available in the Brazilian market, they found values that ranged from 3.77 to 12.68 for acidity and 2.89 to 4.03 for $\mathrm{pH}$. No direct relationship was observed between high acidity and the $\mathrm{pH}$ value of the leaves. The high acidity content may be related to the non-dissociated organic acids and the presence of compounds of an acid character.

In the present study it was possible to observe that the content of the elements aluminum, boron and copper, in all cultivars analyzed, and that the content of zinc in cultivars Frantoio and Arbosana, were below the detection limit of the method used. It was observed that, in general, the minerals present in olive leaves in higher concentration were potassium and calcium, and in lower concentration, iron, magnesium, sodium, manganese, phosphorus and zinc (Table 3). A study by Cavalheiro et al. (2015), who evaluated the mineral content of olive leaves grown in southern Brazil, found aluminum, calcium, iron, potassium, magnesium, phosphorus and sulfur in greater concentration. Bahloul et al. (2014), when evaluating olive leaves grown in Tunisia, obtained higher concentrations of $\mathrm{Ca}$ and $\mathrm{K}$, and in lower concentration $\mathrm{Mg}, \mathrm{Na}$ and $\mathrm{Cu}$, as in the present study. Studies have also shown that the concentration of $\mathrm{Mn}, \mathrm{Fe}, \mathrm{Zn}, \mathrm{Ca}, \mathrm{Mg}, \mathrm{K}$ and $\mathrm{P}$ present in olive leaves of the Koroneiki variety, grown in Greece, was not influenced by the type of soil in which the plants were grown (Chatzistathis et al., 2010).

The composition of olive leaves according to Nogueira (2012) can vary depending on factors such as cultivar, climate, soil, irrigation regime, and the state of development of the plant. The determination of mineral elements present in olive leaves is important both in agriculture and in human nutrition, as it allows the detection of nutritional deficiencies or excesses that can compromise the growth and development of the plant (Fernandez-Hernandez et al., 2010), in addition to evaluate the nutritional value of foods (Sahan et al., 2007).

The leaves showed high concentrations of minerals, mainly potassium and calcium, micronutrients that play important roles in the human body and therefore of great value in the recovery of these minerals from the leaves or even the incorporation of these by-products in food formulations.

\section{Bioactive Compounds}

The composition of bioactive compounds is influenced by intrinsic and extrinsic factors, which results in leaves with differences, varying between cultivars, between

Table 2: Results of physico-chemical analyzes of olive leaves of the cultivars Frantoio, Koroneike, Manzanilha, Arbosana and Arbequina

\begin{tabular}{lccccc}
\hline Determination & Frantoio & Koroneike & Manzanilha & Arbosana & Arbequina \\
\hline Moisture (\%) & $48.48 \pm 0.02 \mathrm{~d}^{1 /}$ & $51.79 \pm 0.16^{\mathrm{c}}$ & $55.79 \pm 0.16^{\mathrm{a}}$ & $55.55 \pm 0.15^{\mathrm{a}}$ & $54.29 \pm 0.41^{\mathrm{b}}$ \\
Ash (\%) & $3.75 \pm 0.04^{\mathrm{NS}}$ & $4.38 \pm 1.46$ & $3.00 \pm 0.01$ & $3.26 \pm 0.04$ & $3.44 \pm 0.11$ \\
Fibers (\%) & $11.02 \pm 0.19^{\mathrm{NS}}$ & $10.45 \pm 1.05$ & $11.01 \pm 1.31$ & $10.46 \pm 0.90$ & $9.32 \pm 0.91$ \\
Lipids (\%) & $6.20 \pm 0.19^{\mathrm{b}}$ & $4.62 \pm 0.12^{\mathrm{d}}$ & $3.77 \pm 0.11^{\mathrm{e}}$ & $7.85 \pm 0.00^{\mathrm{a}}$ & $5.59 \pm 0.34^{\mathrm{c}}$ \\
Protein (\%) & $12.93 \pm 0.49^{\mathrm{NS}}$ & $13.38 \pm 0.25$ & $17.07 \pm 0.25$ & $12.69 \pm 3.01$ & $13.25 \pm 0.25$ \\
Carbohydrates (\%) & $17.55 \pm 0.35^{\mathrm{a}}$ & $15.86 \pm 1.62^{\mathrm{a}}$ & $8.63 \pm 0.46^{\mathrm{b}}$ & $10.64 \pm 2.71^{\mathrm{b}}$ & $14.61 \pm 0.11^{\mathrm{a}}$ \\
Acidity (\%) & $17.96 \pm 1.53^{\mathrm{NS}}$ & $18.70 \pm 0.39$ & $19.26 \pm 1.16$ & $18.15 \pm 1.84$ & $18.26 \pm 1.90$ \\
pH & $5.79 \pm 0.08^{\mathrm{a}}$ & $5.63 \pm 0.04^{\mathrm{a}}$ & $5.86 \pm 0.01^{\mathrm{a}}$ & $5.25 \pm 0.18^{\mathrm{b}}$ & $5.89 \pm 0.04^{\mathrm{a}}$ \\
\hline
\end{tabular}

* Ns Not significant by the $\mathrm{F}$ test of the analysis of variance, considering $5 \%$ of significance. ** $1 /$ Mean $( \pm$ standard deviation) accompanied by the same letter on the same line do not differ from each other by the Tukey test, considering $5 \%$ of significance. 
regions and therefore the importance of this study. In the analysis of bioactive compounds (Table 4), the total chlorophyll content of olive leaves ranged from 0.38 to $0.48 \mathrm{mg} \cdot \mathrm{g}^{-1}$. For chlorophyll 'a', a variation was found from 0.27 to $0.33 \mathrm{mg} \cdot \mathrm{g}^{-1}$ and for chlorophyll ' $b$ ', values ranging from 0.11 to $0.15 \mathrm{mg} . \mathrm{g}^{-1}$ were found . Even though there was no significant difference, the leaves of the cultivar Arbosana were the ones that presented the lowest content of the total chlorophylls, also influencing the lower content of the chlorophylls "a" and "b".

The literature reports that olive leaves grown in Tunisia had a total chlorophyll content between 1.132 to $1.795 \mathrm{mg} . \mathrm{g}^{-1}$, from 0.281 to $0.854 \mathrm{mg} \cdot \mathrm{g}^{-1}$ for chlorophyll 'a' and from 0.851 to $1.114 \mathrm{mg} . \mathrm{g}^{-1}$ for chlorophyll ' $\mathrm{b}$ ', showing that olive concentrations varied with the cultivar (Bahloul et al., 2014). In addition, the chlorophyll content is generally affected by several factors such as photoperiod, nitrogen, temperature, degree of maturity and water (Lee et al., 2011). Oliveira et al. (2016), when evaluating the same cultivars obtained from the same region as those researched in the present study, found higher chlorophyll content, confirming the hypothesis that different harvest times and regions may induce changes in the content of these compounds.

The flavonoid content varied from 9.53 to $20.71 \mathrm{mg}$ EQ. $\mathrm{g}^{-1}$, with the leaves of the cultivar Frantoio showing the highest concentration. The highest results of flavonoids were related to the highest content of phenolic compounds in the leaves of the cultivars Frantoio, Koroneike and Arbosana. These levels are in agreement with those reported for olive leaf extracts from different countries (5.46 to $12.47 \mathrm{mg} \mathrm{EQ.g} \mathrm{g}^{-1}$ ), in addition the cultivar Frantoio showed the highest levels of this compound (Orak et al., 2012), also observed in the present study.

The samples of olive leaves showed levels of carotenoids ranging from 5.20 to $8.21 \mathrm{mg} \beta$-carotene. $\mathrm{g}^{-1}$, with the leaves of the varieties Frantoio and Koroneike being the ones with the highest content. According to Brahmi et al. (2012), when evaluating olive leaves grown in Tunisia, demonstrated that the content of carotenoids and

Table 3: Mineral content in olive leaves of the cultivars Frantoio, Koroneike, Manzanilha, Arbosana and Arbequina

\begin{tabular}{lccccc}
\hline \multirow{2}{*}{ Minerals } & \multicolumn{5}{c}{ Concentration, $\mathbf{x} \pm$ SD $(\mathbf{R S D})^{*}, \boldsymbol{\mu g . g ^ { - 1 }}$} \\
\cline { 2 - 6 } & Frantoio & Koroneike & Manzanilha & Arbosana & Arbequina \\
\hline $\mathrm{Al}$ & $<\mathrm{DL}^{* *}$ & $<\mathrm{DL}$ & $<\mathrm{DL}$ & $<\mathrm{DL}$ & $<\mathrm{DL}$ \\
$\mathrm{B}$ & $<\mathrm{DL}$ & $<\mathrm{DL}$ & $<\mathrm{DL}$ & $<\mathrm{DL}$ & $<\mathrm{DL}$ \\
$\mathrm{Ca}$ & $3.92 \pm 0.21(5.3)$ & $2.98 \pm 0.18(6.0)$ & $1.94 \pm 0.19(9.8)$ & $2.91 \pm 0.19(6.5)$ & $2.45 \pm 0.12(4.9)$ \\
$\mathrm{Cu}$ & $<\mathrm{DL}$ & $<\mathrm{DL}$ & $<\mathrm{DL}$ & $<\mathrm{DL}$ & $<\mathrm{DL}$ \\
$\mathrm{Fe}$ & $0.035 \pm 0.002(5.7)$ & $0.045 \pm 0.002(4.4)$ & $0.03 \pm 0.002(6.7)$ & $0.047 \pm 0.002(4.2)$ & $0.0097 \pm 0.008(8.2)$ \\
$\mathrm{K}$ & $7.76 \pm 0.35(4.5)$ & $6.39 \pm 0.31(4.9)$ & $5.21 \pm 0.32(6.1)$ & $5.72 \pm 0.10(1.8)$ & $8.0 \pm 0.3(3.4)$ \\
$\mathrm{Mg}$ & $0.60 \pm 0.02(1.2)$ & $0.50 \pm 0.03(6.0)$ & $0.39 \pm 0.02(5.1)$ & $0.58 \pm 0.02(3.4)$ & $0.51 \pm 0.02(3.9)$ \\
$\mathrm{Na}$ & $0.10 \pm 0.01(10.0)$ & $0.14 \pm 0.006(4.3)$ & $0.084 \pm 0.002(2.3)$ & $0.20 \pm 0.02(10.0)$ & $0.036 \pm 0.003(8.3)$ \\
$\mathrm{Mn}$ & $0.06 \pm 0.003(5.0)$ & $0.016 \pm 0.0012(7.5)$ & $0.05 \pm 0.005(10.0)$ & $0.012 \pm 0.009(7.5)$ & $0.02 \pm 0.001(5.0)$ \\
$\mathrm{P}$ & $0.03 \pm 0.002(6.7)$ & $0.05 \pm 0.004(8.0)$ & $0.013 \pm 0.10(7.7)$ & $0.05 \pm 0.004(8.0)$ & $0.05 \pm 0.002(4.0)$ \\
$\mathrm{Zn}$ & $<\mathrm{DL}$ & $0.02 \pm 0.0019(9.5)$ & $0.01 \pm 0.006(6.0)$ & $<\mathrm{DL}$ & $0.04 \pm 0.0023(5.6)$ \\
\hline
\end{tabular}

* Relative standard deviation (RSD). **DL- Detection limited

Table 4: Bioactive compounds present in the leaves of different olive cultivars

\begin{tabular}{|c|c|c|c|c|c|}
\hline Determination & Frantoio & Koroneike & Manzanilha & Arbosana & Arbequina \\
\hline Total Chlorophylls(mg.g $\left.\mathrm{g}^{-1}\right)$ & $0.48 \pm 0.02^{\mathrm{NS}}$ & $0.47 \pm 0.04$ & $0.46 \pm 0.01$ & $0.38 \pm 0.02$ & $0.44 \pm 0.07$ \\
\hline Chlorophyll 'a'(mg.g $\left.{ }^{-1}\right)$ & $0.33 \pm 0.01^{\mathrm{NS}}$ & $0.32 \pm 0.03$ & $0.32 \pm 0.00$ & $0.27 \pm 0.02$ & $0.30 \pm 0.05$ \\
\hline Chlorophyll ‘b’(mg.g-1) & $0.15 \pm 0.00^{\mathrm{a} 1 /}$ & $0.15 \pm 0.01^{\mathrm{ab}}$ & $0.14 \pm 0.01^{\mathrm{ab}}$ & $0.11 \pm 0.01^{\mathrm{b}}$ & $0.14 \pm 0.03^{\mathrm{ab}}$ \\
\hline Carotenoids (mg â-carotene.g- ${ }^{1}$ ) & $8.09 \pm 0.48^{\mathrm{a}}$ & $8.21 \pm 0.10^{\mathrm{a}}$ & $6.87 \pm 0.35^{\mathrm{bc}}$ & $5.69 \pm 0.23^{\mathrm{bc}}$ & $5.20 \pm 0.26^{c}$ \\
\hline Phenolics compounds(mg EAG.g $\left.{ }^{-1}\right)$ & $9.82 \pm 0.23^{\mathrm{a}}$ & $10.88 \pm 0.52^{\mathrm{a}}$ & $8.24 \pm 0.63^{\mathrm{b}}$ & $10.00 \pm 0.32^{\mathrm{a}}$ & $6.51 \pm 009^{c}$ \\
\hline Flavonoids(mg EQ.g $\left.{ }^{-1}\right)$ & $20.71 \pm 0.69^{\mathrm{a}}$ & $12.69 \pm 0.85^{\mathrm{b}}$ & $9.53 \pm 0.008^{c}$ & $13.13 \pm 0.63^{\mathrm{b}}$ & $10.18 \pm 0.72^{\mathrm{c}}$ \\
\hline Hydrolyzed Tannins (mg EAG.g ${ }^{-1}$ ) & $7.34 \pm 0.93^{\mathrm{ab}}$ & $8.2 \pm 0.70^{\mathrm{a}}$ & $6.52 \pm 0.04^{b}$ & $6.33 \pm 0.48^{\mathrm{b}}$ & $7.39 \pm 0.01^{\mathrm{ab}}$ \\
\hline Condensed Tannins (mg ECAT.g ${ }^{-1}$ ) & $0.01 \pm 0.00^{\mathrm{a}}$ & $0.0002 \pm 0.00^{\mathrm{ab}}$ & $0.0004 \pm 0.00^{\mathrm{abc}}$ & $0.0040 \pm 0.00^{c}$ & $0.0016 \pm 0.00^{\circ}$ \\
\hline Oleuropeín $\left(\mu \mathrm{g} \cdot \mathrm{g}^{-1}\right)$ & $43.33 \pm 2.93$ & $40.97 \pm 1.49$ & $42.01 \pm 8.20$ & $38.89 \pm 3.10$ & $32.36 \pm 4.02$ \\
\hline$\alpha$-tocopherol(mg.100g $\left.\mathrm{g}^{-1}\right)$ & 220541.20 & 168482.92 & 254071.69 & 51037.10 & 63436.79 \\
\hline$\gamma$-tocopherol(mg.100g-1) & 17620.51 & 13759.00 & 15028.45 & 14720.15 & 14647.88 \\
\hline$\Delta$-tocopherol $\left(\mathrm{mg} .100 \mathrm{~g}^{-1}\right)$ & 12889.38 & 7808.48 & 8083.84 & 9449.59 & 7568.29 \\
\hline
\end{tabular}

* NS Not significant by the $\mathrm{F}$ test of the analysis of variance, considering $5 \%$ of significance. ** 1/Mean ( \pm standard deviation) accompanied by the same letter on the same line do not differ from each other by the Tukey test, considering $5 \%$ of significance. 
chlorophylls are influenced by the age of the leaves. According to the authors, higher contents were observed in the leaves harvested in February, when the leaves complete their growth, than in October, when the leaves were still growing. In the present study, there was no evidence of a direct relationship between the content of carotenoids and the content of chlorophylls, where the leaves of the cultivar Arbosana presented one of the lowest contents of carotenoids and also of chlorophylls; however, the leaves of the cultivars Manzanilha and Arbequina also had the lowest carotenoid content, but high chlorophyll content. In addition to harvest time, carotenoid content depends on several factors, including genetic variety and post-harvest handling (Capecka et al., 2005).

The content of hydrolyzed tannins ranged from 6.33 to $8.2 \mathrm{mg} \mathrm{EAG.g}^{-1}$, again highlighting the leaves of the cultivar Koroneike. The higher content of hydrolyzable tannins was also associated with the higher content of phenolic compounds in the leaves of the cultivars Frantoio, Koroneike and Arbosana. The condensed tannin content was not very expressive, being the cultivar Frantoio, the one that presented the highest concentration. Brahmi et al. (2013) when evaluating olive leaves, harvested in two periods, and observed that the highest tannin content was obtained in the month of October (1st period), and it was found that in the month of January (2nd period) there was a relative decrease in the content of tannins, suggesting that the vegetative cycle of the olive tree affects the content of tannins.

In the present study, a significantly higher content for hydrolyzed tannins was found in relation to the condensed tannin content; which was also observed in the work carried out by Abbeddou et al. (2011). There are few studies in the literature that analyze tannins in olive leaves, but comparing them with the leaves content of other plants, it can be considered that olive leaves have a high tannin content, substances with recognized therapeutic activities, associated with its ability to complex with different compounds.

The content of phenolic compounds in olive leaves ranged from 6.51 to $10.88 \mathrm{mg} \mathrm{EAG.g}^{-1}$, with the cultivars Manzanilha and Arbequina having the lowest content. In studies by Ahmad-Qasem et al. (2013), when studying the effects of drying and dehydration during the storage of leaves of the cultivar Serrana (Spain), obtained an initial content of phenolic compounds of $8.20 \mathrm{mg} \mathrm{EAG.g}^{-1}$, a value similar to those found in the present study.

According to Cavalheiro et al. (2015), when evaluating the content of phenolic compounds in some cultivars (Arbosana and Koroneike) of olive leaves grown in Santa Catarina, identified the cultivar Arbosana with the highest content of phenolic compounds. However, the authors found in the Koroneike cultivar the lowest content of phenolic compounds, a result opposite to that observed in the present study, where this cultivar presented the highest concentration. It is known that different variables can interfere with the content and synthesis of phenolic compounds present in the olive tree, whether in the oil, fruits or leaves, variables that include the cultivar, the position of the tree, the type of soil and the minerals present, geographic location, solar influence, among others. (Otero et al., 2020).

Oleuropein is the most abundant phenolic compound in olive leaves and is considered an ester of elenolic acid and 3,4-dihydroxyphenyl ethanol that can reach concentrations of up to $90 \mathrm{mg}^{\mathrm{g}} \mathrm{g}^{-1}$ of dry leaf (Tan et al., 2003). These fluctuations were observed in the present study, among the cultivars studied, the one with the highest oleuropein content was Frantoio $\left(43.33 \mu \mathrm{g} \cdot \mathrm{g}^{-1}\right)$, followed by Manzanilha $\left(42.01 \mu \mathrm{g} \cdot \mathrm{g}^{-1}\right)$, the cultivar Arbequina in turn, it presented the lowest concentration of the compound $\left(32.36 \mu \mathrm{g} \cdot \mathrm{g}^{-1}\right)$. In the present study, oleuropein had a low content, which could be associated with the extraction method.

Pacetta (2013), studying different methodologies for obtaining olive leaf extracts containing oleuropein, demonstrated that using ethanol combined with acetic acid, the oleuropein content was $4.80 \mathrm{~g} .100 \mathrm{~g}^{-1}$, a content higher than the others evaluated methods and solvents. Böhmer-Maas et al. (2020), when evaluating different conditions of extraction of oleuropein using methanol as solvent, found values that varied between 4.9 and $7.3 \mathrm{mg} \cdot \mathrm{kg}^{-1}$. As is known, the polyphenols content of the extracts can change depending on the solvent used in the extraction, due to the change in polarity in the different extraction processes (Luthria et al., 2006). Different authors have reported that flavonoids and oleuropein are the main components identified in ethanol extracts, in aqueous extracts, hydroxytyrosol and phenolic acids prevail. (Lee et al., 2009; Herrero et al., 2011; Quirantes-Piné et al., 2012). According to Otero et al. (2020), oleuropein is used as an adjuvant in food and cosmetic technologies and therapeutic processes in the treatment of diseases, where it has been gaining prominence in research due to its anti-inflammatory activities, antimicrobial, antioxidant and hypoglycemic, among others.

The tocopherol content (alpha, delta and gamma) was determined in the different cultivars, Arbequina being the leaf that had the highest content of $\alpha$-tocopherol (63436.79 mg. $100 \mathrm{~g}^{-1}$ ) among the cultivars while Frantoio stood out from the others in relation to the concentration of ã and $\ddot{A}$ tocopherols (17620.51 and $12889.38 \mathrm{mg}^{100 \mathrm{~g}^{-1}}$ ) respectively. Data regarding tocopherols in olive leaves in the literature are scarce, since these determinations are commonly made in olive oil, not in olive leaves. 


\section{Fatty acid profile}

The composition of fatty acids present in the cultivars studied showed very different profiles between the leaves (Table 5).

As can be seen in Table 5, the cultivars Frantoio, Manzanilla and Kororeike have a higher concentration of saturated fatty acids, while Arbequina and Arbosana showed higher levels of unsaturated fatty acids. Frantoio leaves are rich in tricosanoic acid (43.62\%), Manzanilla $(64.70 \%)$ and Koroneike $(44.15 \%)$ in hexanoic acid, Arbequina in docosadienic acid (38.00\%) and Arbosan in eicosapentaenoic (39.09\%).

Cavalheiro et al. (2014) evaluated the fatty acid composition of olive leaves of the cultivar Arbequina in the south of Rio Grande do Sul and observed a higher concentration of linolenic acid (46\%). De Oliveira et al. (2012) performed the same evaluations on Arbequina leaves grown in southern Minas Gerais, where they found oleic acid (61.30\%) as the major acid.

The composition of fatty acids can be affected by environmental and growing conditions. Temperature is of great importance in the composition of fatty acids, regulating fatty acid desaturases, the literature reports that temperature is inversely proportional to the fatty acid content, that is, low temperatures tend to increase the concentration of polyunsaturated fatty acids in plants, maintaining the fluidity of biological membranes. In addition to these, other factors such as the degree of ripeness, processing conditions and temperature are reported, as well as moisture, light intensity, soil composition and evapotranspiration also reflect on the composition of these fatty acids. (Ballus et al., 2014).

Leaves samples were collected in the spring, which has an average solar radiation of $20\left(\mathrm{MJm}^{2}\right)$, an average temperature of $25^{\circ} \mathrm{C}$ and little rainfall. These factors are relevant to vegetables and, consequently, compounds originating from the secondary metabolism of these plants. Among the macromolecules present in olive leaves, high levels of fibers and proteins found suggest that olive leaves grown in this region can serve as a food supplement, as well as for enriching food products. The composition of fatty acids showed distinct and varied profiles between the leaves, in relation to saturated and unsaturated fatty acids, which is presented in a positive way, since these matrices are sources of different fatty acids and can be isolated and used by the pharmaceutical industries, food and animal feed industries.

One of the most abundant by-products of olive growing is the leaves of the olive tree, whether they come

Table 5: Fatty acid profile of olive leaves from southern Brazil

\begin{tabular}{|c|c|c|c|c|c|}
\hline \multirow{2}{*}{ Fatty acids \% } & \multicolumn{5}{|c|}{ Cultivars } \\
\hline & Frantoio & Koroneike & Manzanilha & Arbosana & Arbequina \\
\hline C 6 & - & 44.15 & 64.70 & - & - \\
\hline $\mathrm{C} 8$ & 0.56 & 2.82 & 3.76 & - & - \\
\hline C 10 & 2.72 & 2.60 & 1.04 & 1.47 & - \\
\hline C 11 & - & 0.15 & - & - & - \\
\hline C 13 & - & - & - & 0.28 & - \\
\hline C 14 & 0.73 & - & - & - & - \\
\hline C 15 & 1.05 & 0.42 & - & 0.68 & - \\
\hline C $16: 1$ & 0.32 & - & - & - & - \\
\hline C 20 & 0.36 & 0.18 & - & - & - \\
\hline C18:3 & 1.21 & 0.52 & 11.11 & 15.06 & 20.51 \\
\hline C 20:1 & 0.51 & 0.53 & - & - & - \\
\hline C 21 & 19.22 & 12.35 & - & - & - \\
\hline C 20:2 & 6.50 & - & 6.04 & 5.24 & - \\
\hline C 20:4 & 3.94 & 2.63 & - & - & 4.40 \\
\hline C 22 & 2.45 & 1.58 & 1.25 & - & - \\
\hline C $20: 3$ & 0.45 & - & - & - & 3018 \\
\hline C $22: 1$ & 1.19 & 0.54 & - & - & - \\
\hline C 23 & 43.62 & 24.85 & 8.68 & 29.33 & 4.15 \\
\hline C 22:2 & 11.35 & 4.16 & 1.50 & 4.28 & 39.09 \\
\hline C 24 & 0.85 & - & - & 4.04 & 1.65 \\
\hline C 20:5 & 2.11 & 0.67 & 1.90 & 38.00 & - \\
\hline C 24:1 & 0.81 & - & - & - & - \\
\hline C $22: 6$ & - & 1,83 & - & 1.60 & - \\
\hline Saturated \% & 71.58 & 89.11 & 79.44 & 35.81 & 23.11 \\
\hline Insaturated $\%$ & 28.42 & 10.99 & 20.55 & 64.19 & 76.99 \\
\hline
\end{tabular}

Rev. Ceres, Viçosa, v. 68, n.6, p. 511-520, nov/dec, 2021 
from olive oil production or as a product of olive tree pruning, representing a high cost for producers, due to their removal and elimination. Therefore, the valuation and use of these by-products is of great economic importance due to their low cost and large accumulation in these agricultural activities. Althrough the recovery of bioactive compounds present in the olive by-products (leaves), ingredients with high added value can be obtained and are of interest to several areas such as: pharmaceutical, food and cosmetics. For the different cultivars studied, different answers were found, and this information is important to optimize industrial processes (Lorini et al., 2020).

\section{CONCLUSIONS}

Olive leaves cultivated in the southern region of Brazil showed a high content of bioactive compounds, mainly flavonoids and carotenoids, thus indicating that olive leaves can be considered as a source of bioactive compounds, with possible use for animal feed and as well as pharmaceutical industry

The search for new destinations for agricultural waste is a constant concern, aiming to find new ways to add value to the products, as well as to reduce the contamination of the environment, mainly of the soil, with the disposal of these raw materials. Therefore, in view of the results found in this research, one can observe the potential that olive leaves represent in terms of obtaining and extracting compounds of interest, and with these new destinations for these by-products are reported.

\section{ACKNOWLEDGEMENTS, FINANCIAL SUPPORT AND FULL DISCLOSURE}

To the Coordenação de Aperfeiçoamento de Pessoal de Nível Superior (Capes) and Fundação de Amparo à Pesquisa do Estado do Rio Grande do Sul (Fapergs), for financial support. The authors report that there is no conflict of interest.

\section{REFERENCES}

Abbeddou S, Rihawi S, Hess HD, Iñiguez L, Mayer AC \& Kreuzer M (2011) Nutritional composition of lentil straw, vetch hay, olive leaves, and saltbush leaves and their digestibility as measured in fat-tailed sheep. Small Ruminant Research, 96:126-135.

Ahmad-Qasem MH, Barrajón-Catalán E, Micol V, Mulet A \& García-Pérez JV (2013) Influence of freezing and dehydration of olive leaves (var. Serrana) on extract composition and antioxidant potential. Food Research International, 50:189196.

AOAC - Association of Official Analytical Chemists (1995) Official Methods of analysis of AOAC International. $16^{\text {th }}$ ed. Arlington, AOAC. 894p

Bahloul N, Kechaou N \& Mihoubi NB (2014) Comparative investigation of minerals, chlorophylls contents, fatty acid composition and thermal profiles of olive leaves (Olea europeae L.) as by-product. Grasas y Aceites, 65:35-43.
Ballus CA, Meinhart AD, De Souza-Campos FA, Da Silva LFDO, De Oliveira AF \& Godoy HT (2014) A quantitative study on the phenolic compound, tocopherol and fatty acid contents of monovarietal virgin olive oils produced in the southeast region of Brazil. Food Research International, 62:74-83.

Bligh EG \& Dyer WJ (1959) A rapid method of total lipid extraction and purification. Canadian journal of biochemistry and physiology, 37:911-917

Boudhrioua N, Bahloul N, Slimen IB \& Kechaou N (2009) Comparison on the total phenol contents and the color of fresh and infrared dried olive leaves. Industrial Crops and Products, 29:412-419.

Brahmi F, Mechri B, Dabbou S, Dhibi M \& Hammami M (2012) The efficacy of phenolics compounds with different polarities as antioxidants from olive leaves depending on seasonal variations. Industrial Crops and Products, 38:146-152.

Brahmi F, Mechri B, Dhibi M \& Hammami M (2013) Variations in phenolic compounds and antiradical scavenging activity of Olea europaea leaves and fruits extracts collected in two different seasons. Industrial Crops and Products, 49:256- 264.

Brune M, Hallberg L \& Skanberg A (1991) Determination of Ironbinding Phenolic groups in Foods. Journal of Food Science, 56:128-131.

Böhmer-Maas BW, Otero DM, Zambiazi RC \& Aranha BC (2020) Optimization of the extraction of phenolic compounds from olive pomace using response surface methodology. Revista Ceres, 67:181-190

Capecka E, Mareczek A \& Leja M (2005) Antioxidant activity of fresh and dry herbs of some Lamiaceae species. Food Chemistry, 93:223-226.

Cavalheiro CV, Rosso VD, Paulus E, Cichoski AJ, Wagner R, Menezes CR \& Barin JS (2014) Composição química de folhas de oliveira (Olea europaea L.) da região de Caçapava do Sul, RS. Ciência Rural, 44:1874-1879.

Cavalheiro CV, Picoloto RS, Cichoski AJ, Wagner R, Menezes CR, Zepka LQ, Da Croce DM \& Barin JS (2015) Olive leaves offer more than phenolic compounds - Fatty acids and mineral composition of varieties from Southern Brazil. Industrial Crops and Products, 71:122-127.

Chatzistathis T, Therios I, Alifragis D \& Dimassi A (2010) Effect of sampling time and soil type on $\mathrm{Mn}, \mathrm{Fe}, \mathrm{Zn}, \mathrm{Ca}, \mathrm{Mg}, \mathrm{K}$ and $\mathrm{P}$ concentrations of olive (Olea europaea L., cv. 'Koroneiki') leaves. Scientia Horticulturae, 126:291-296.

Coutinho EF (2007) A cultura da Oliveira. $1^{\text {st }}$ ed. Pelotas, Embrapa Clima Temperado. $143 \mathrm{p}$.

Coppa CFSC, Rosin RE, De Oliveira CAF, Rodrigues CEC \& Gonçalves CB (2017) Extraction of oleuropein from olive leaves using a hydroalcoholic solvent. Brazilian Journal of Food Technology, 20:e2016169.

De Oliveira MC, Ramos JD, Pio R \& Das Graças-Cardoso M (2012) Características fenológicas e físicas e perfil de ácidos graxos em oliveiras no sul de Minas Gerais. Pesquisa Agropecuária Brasileira, 47:30-35.

De Vos RC, Moco S, Lommen A, Keurentjes JJ, Bino RJ \& Hall RD (2007) Untargeted large-scale plant metabolomics using liquid chromatography coupled to mass spectrometry. Nature protocols, 2:778-791.

Erbay Z \& Icier F (2009) Optimization of hot air drying of olive leaves using response surfasse methodology. Journal of Food Engineering, 91:533-541.

Fernández-Bolaños J, Rodríguez G, Rodríguez R, Guillén R \& Jiménez A (2006) Potential use of olive by-products, Extraction of interesting organic compounds from olive oil waste. Grasas y Aceites, 57:95-106. 
Fernandez-Hernandez A, Mateos R, Garcia-Mesa JA, Beltran G \& Fernandez-Escobar R (2010) Determination of mineral elements in fresh olive fruits by flame atomic spectrometry. Spanish Journal of Agricultural Research, 8:1183-1190.

Funari CS \& Ferro VO (2006) Análise de própolis. Ciência e Tecnologia de Alimentos, 26:171-178.

Galanakis CM, Tsatalas P \& Galanakis IM (2018) Phenols from olive mill wastewater and other natural antioxidants as UV filters in sunscreens. Environmental Technology \& Innovation, $9: 160 " 168$

Gorzynik-Debicka M, Przychodzen P, Cappello F, KubanJankowska A, Marino-Gammazza A \& Knap N (2018). Potential health benefits of olive oil and plant polyphenols. International Journal of Molecular Sciences, 19:686.

Guo Z, Jia X, Zheng Z, Lu X, Zheng Y, Zheng B \& Xiao J (2018) Chemical composition and nutritional function of olive (Olea europaea L.): a review. Phytochemistry Reviews, 17:10911110 .

Herrero M, Temirzoda TN, Segura-Carretero A, Quirantes R, Plaza M \& Ibañez E (2011) New possibilities for the valorization of olive oil by-products. Journal of Chromatography A, 1218:7511-7520.

Jabalbarezi-Hukerdi Y, Fathi MH, Rashidi L \& Ganjkhanlou M (2018) The Study of Physicochemical Properties and Nutrien Composition of Mari Olive Leaf Cultivated in Iran. Nutrition and Food Sciences Research, 5:39"46.

Jane M, McKay J \& Pal S (2019) Effects of daily consumption of psyllium, oat bran and polyG.ycopleX on obesity-related disease risk factors: A critical review. Nutrition, 57:84-91.

Lee OH, Lee BY, Lee J, Lee HB, Son JY, Park CS, Shetty K \& Kim YC (2009) Assessment of phenolics-enriched extract and fractions of olive leaves and their antioxidant activities. Bioresource Technology, 100:6107-6113.

Lama-Muñoz A, Contreras M del M, Espínola F, Moya M, Romero I \& Castro E (2020) Content of phenolic compounds and mannitol in olive leaves extracts from six Spanish cultivars: Extraction with the Soxhlet method and pressurized liquids. Food Chemistry, 320:126626.

Lee YJ, Yang CM, Chang LW \& Shen Y (2011) Effects of nitrogen status on leaf anatomy, chlorophyll content and canopy reflectance of paddy rice. Botanical Studies, 52:295-303.

Lichtenthaler HK (1987) Chlorophylls and carotenoids: pigments of photosynthetic biomembranes. Methods Enzymol, 148:350381

Lorini A, Aranha BC, Antunes BF, Otero DM, Jacques AC \& Zambiazi RC (2020) Metabolic profile of olive leaves of different cultivars and collection times. Food Chemistry, 128758 .

Luthria DL, Mukhopadhyay S \& Kwansa AL (2006) A systematic approach for extraction of phenolic compounds using parsley (Petroselinum crispum) flakes as a model substrate. Journal of the Science of Food and Agriculture, 86:1350-1358.

Lunkes LBF \& Hashizume LN (2014) Evaluation of the pH and titratable acidity of teas commercially available in Brazilian market. Revista Gaúcha de Odontologia, 62:59-64.

Martín-García AI, Moumen A, Yáñez-Ruiz DR \& Molina-Alcaide E (2003) Chemical composition and nutrients availability for goats and sheep of two-stage olive cake and olive leaves. Animal Feed Science and Technology, 107:61-74.

Nogueira FAM (2012) Contribuição para caracterização de "Azeitonas de mesa mistas ao natural" produzidas de forma tradicional em Trás-os-Montes: Aspectos morfológicos, químicos e microbiológicos. Master Dissertation. Instituto Politécnico de Bragança, Bragança. 87p.
Oliveira FM, Antunes BF, Jacques AC \& Zambiazi RC (2016) Teor de clorofila em folhas de oliveira cultivadas na região da campanha gaúcha. In: $15^{\text {a }}$ Mostra da Produção Universitária, Rio Grande. Proceedings, Universidade Federal de Rio Grande. ISSN: $2317-$ 4420.

Oreste EQ, Jesus A, Oliveira RM, Silva MM, Vieira MA \& Ribeiro AS (2013) New design of cold finger for sample preparation in open system: determination of $\mathrm{Hg}$ in biological samples by $\mathrm{CV}$ AAS. Microchemical Journal, 109:5-9.

Orak HH, Isbilir SS \& Yagar H (2012) Determination of Antioxidant Properties of Lyophilized Olive Leaf Water Extracts Obtained from 21 Different Cultivars. Food Science Biotechnology, 21:1065-1074.

Otero DM, Oliveira FM, Lorini A, Antunes BF, Oliveira RM \& Zambiazi RC (2020) Oleuropein: Methods for extraction, purifying and applying. Revista Ceres, 67:240-254.

Pacetta CF (2013) Estudo de diferentes metodologias para obtenção de extratos de folhas de oliveira (Olea europaea) contendo Oleuropeína. Master Dissertation. Universidade de São Paulo, Pirassununga. 82p.

Price ML, Scoyoc SV \& Butler LG (1978) A Critical Evaluation of the Vanillin Reaction as an Assay for Tannin in Sorghum Grain. Journal Agriculture Food Chemistry, 26:1214-1218.

Quirantes-Piné R, Lozano-Sánchez J, Herrero M, Ibáñez E, Segura-Carretero A \& Fernández-Gutiérrez A (2012) HPLC-ESIQTOF-MS as a powerful analytical tool for characterising phenolic compounds in olive-leaf extracts. Phytochemical Analysis, 24:213-223.

Rahmanian N, Jafari SM \& Wani TA (2015) Bioactive profile, dehydration, extraction and application of the bioactive components of olive leaves. Trends in Food Science and Technology, 42:150-172.

Rodriguez-Amaya DB (2001) A guide to carotenoid analysis in food. Washington, International Life Sciences Institute. 64p.

Rosa AD, Junges A, Fernandes IA, Cansian RL, Corazza ML, Franceschi E, Backes GT \& Valduga E (2019) High pressure extraction of olive leaves (Olea europaea): bioactive compounds, bioactivity and kinetic modelling. Journal of Food Science and Technology, 56:3864-3876.

Sahan Y, Basoglu F \& Gucer S (2007) ICP-MS analysis of a series of metals (namely: $\mathrm{Mg}, \mathrm{Cr}, \mathrm{Co}, \mathrm{Ni}, \mathrm{Fe}, \mathrm{Cu}, \mathrm{Zn}, \mathrm{Sn}, \mathrm{Cd}$ and $\mathrm{Pb}$ ) in black and green olive samples from Bursa, Turkey. Food Chemistry, 105:395-399.

Kubola J \& Siriamornpun S (2008) Phenolic contents and antioxidant activities of bitter gourd (Momordica charantia L.) leaf, stem and fruit fraction extracts in vitro. Food Chemistry, 110:881-890

Talhaoui N, Taamalli A, Gómez-Caravaca AM, FernándezGutiérrez A \& Segura-Carretero A. (2015) Phenolic compounds in olive leaves: Analytical determination, biotic and abiotic influence, and health benefits. Food Research International, 77:92-108.

Tarchoune I, Sgherri C, Eddouzi J, Zinnai A, Quartacci MF \& Zarrouk M (2019) Olive leaf addition increases olive oil nutraceutical properties. Molecules, 24:545.

Tan H, Tuck K, Stupans I \& Hayball P (2003) Simultaneous determination of oleuropein and hydroxytyrosol in rat plasma using liquid chromatography with fluorescence detection. Journal of Chromatography B, 785:187-191.

Visioli F \& Galli C (2002) Biological properties of olive oil phytochemicals. Critical Reviews in Food Science and Nutrition, 42:209-221.

Zambiazi RC (1997) The role of endogenous lipid components on vegetable oil stability. Doctoral Thesis. University of Manitoba, Winnipeg. 304p. 